\title{
Conceptual design of a crime regulatory system for Mexico
}

\author{
D. E. Santos-Reyes \\ I'CHI ID+I, Santos Reyes Yucuna, Huajuapan de Leon, Oaxaca, Mexico
}

\begin{abstract}
Over the last two decades, in addition to traditional crime, organised crime has permeated the fabric of Mexican communities and institutions. A great deal of effort has been put in by Mexican governments in order to address the increasing crime issues. It seems, however, that these efforts have faced a large number of conflicting conditions due to the complexity of not only crime systems, but also other systems that constitute the whole country. What would be the ideal crime control system for Mexico? What needs to be changed in the existing regulatory system? This paper presents an ongoing process of the design of a systemic regulatory system in order disrupt the growth of crime in Mexico. This control system intends to assist policy makers and decision makers to address the control of crime more effectively.

Keywords: crime, S-curve, systems, control.
\end{abstract}

\section{Introduction}

Over the last two decades, in addition to traditional crime, organised crime has permeated the fabric of Mexican communities and institutions. In addition to the increasing crime, corruption and impunity seem are rooted in all levels of Mexican society and institutions. A great deal of effort has been put by Mexican governments in order to address these issues. It seems, however, that these efforts have faced a large number of conflicting conditions due to the complexity of not only crime systems, but also other systems that constitute the whole country. Crime in particular is a self-organised phenomena that adapts through time, i.e., it follows a well defined patterns of temporall diffusion $[1,2]$. What would be the ideal crime control system for Mexico? What needs to be changed in the existing regulatory system? This paper presents an ongoing process of the 
design of a systemic regulatory system in order disrupt the growth of crime in Mexico. This control system intends to assist policy makers and decision makers to address the control of crime more effectively. In the remaining sections of the paper, the literature review, the context of crime control in Mexico, the development of a conceptual crime control model, and conclusions and further research are presented.

\section{Crime and control}

\subsection{Crime issues}

Over the last two decades, there has been a great effort by academics to develop a better understanding of crime and means to reduce it [1-6]. For example, Piccato $[3,4]$ analyses the perception of crime during the last century in Mexico City. Several crime issues, such as sources of crime, police and judicial corruption practice, gender violence and juvenile delinquency are addressed. It is further discussed the reactions of urban communities and civil organisations against crime. Buffington [5] contends that crime in Mexico has followed welldefined patterns since the Mexican independence era. He emphasises that the Mexican justice system consolidated through time but finally superseded. In general, crime in Mexico seems to be an orderly process that grow slowly at the beginning, followed by an accelerating growth, culminating insaturation [8]. There is a need to disrupt this steadily growing crime.

\subsection{Control issues}

Gorsky et al. [7] and Gorsky and Stepanov [8] emphasise that systems achieve the desired outcome through negative feedback control mechanisms. Given a set of specifications for some desired conditions, these mechanisms, also known has homeostasis, can produce the specified output even though the actions needed to do so vary from one instant to another. Moreover, homeostatic mechanisms are adaptive mechanisms because they are able to vary their actions when they are needed in order to continue producing the desired outcome despite external disturbances. Regarding crime, what would be the ideal crime control system for Mexico? What needs to be changed in the existing regulatory system?

\section{Crime control situation in Mexico}

\subsection{The situation}

Figure 1 shows an overall structure of the crime control situation in Mexico in recursive levels. Figure 1(a) describes the whole system's constituents, how the constituent elements are related to each other, and the key characteristics of the components and their relationship. The total Mexican crime control management situation exhibits three interrelated key characteristics namely crime, impunity, and corruption (Figure 1(b)). 


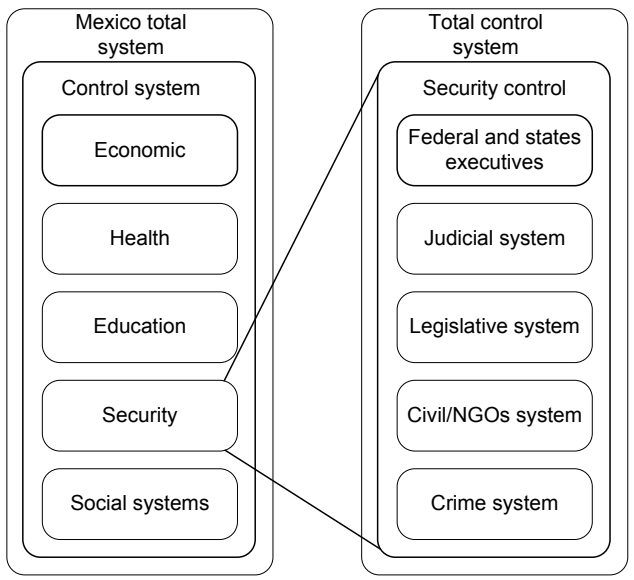

(a)

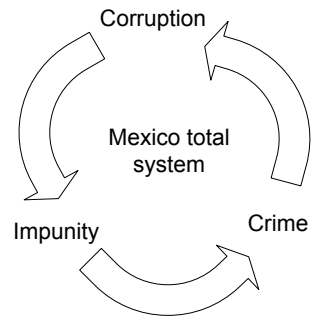

(b)

Figure 1: The total control of crime situation and its emergent properties.

\subsubsection{Crime system}

The more traditional forms of crime, such as robberies/assaults, burglaries, murdering/injuries, rape and sexual violence, child pornography, racism/discrimination, kidnappings, and antisocial behaviour are expanding and adapting to the modern forms of the Mexican's life style. Moreover, offenders are evolving into new forms of activity with the use of modern information technology to commit crimes such as frauds, piracy, and different forms of cyber-crime, and is increasing with time. As argued elsewhere [1,2] crime is an organised process that grow slowly in the beginning, followed by an accelerating and then decelerating growth, culminating in saturation. Figure 2 shows a typical Mexican crime diffusion process that has been steadily growing since the beginning of the last century. With a growth rate of around $4 \%(b=0.0397)$ the traditional forms of crime is reaching its midpoint, $t_{m}$, of growth around 2022 and steady state, $\mathrm{k}$, of cumulative crime number of $1.7245 \mathrm{e}+007$.

Furthermore, it is not only the traditional forms of crime have increased, also organised crime is on the rise. There are many criminal organisations, including drug trafficking organisations, smuggling gangs, alien smuggling networks, including foreign criminal transnational organisations operating in Mexico. Organised crime is evolving into more sophisticated modus operandi in order to sustain its market niche.

\subsubsection{The civil associations and NGOs}

At the wider level of the total system, Mexicans, either in civil associations, or in NGO, have realised demonstrations throughout the country to express their concern about the increasing rate of crime of all kind, including fraudelent elections, systematic corruption of government at all levels, and the excessive use of force in the practice of policing. It seems that significant effort has been made by both the controllers and the controlled in order to address the endemic 


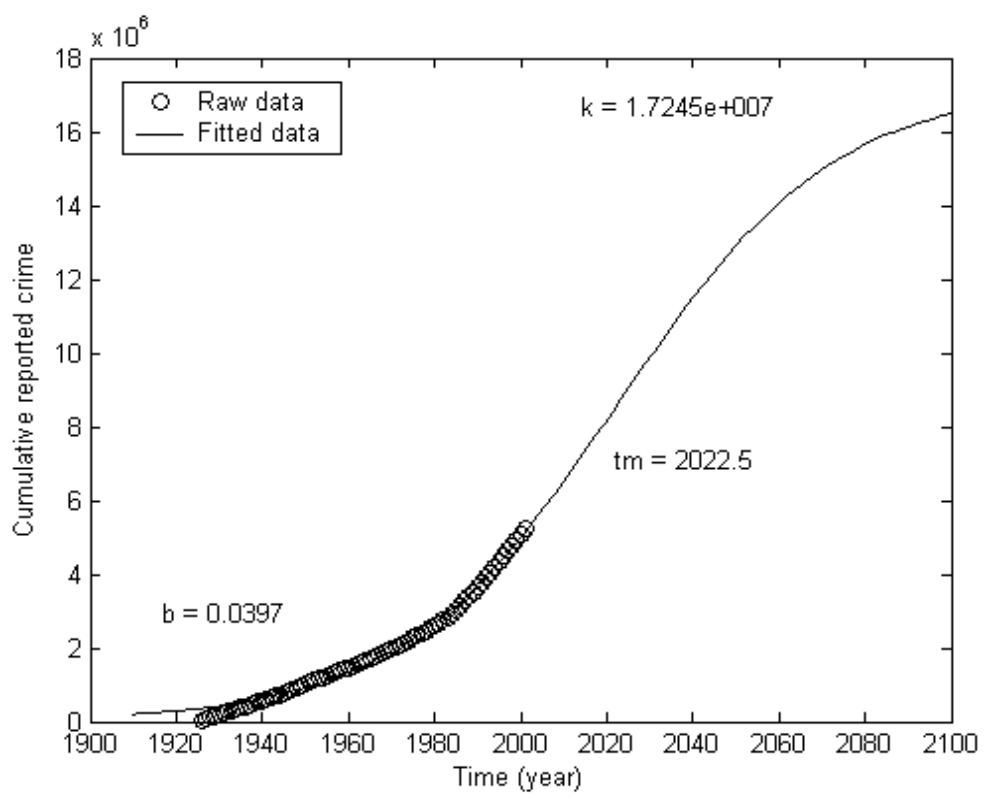

Figure 2: $\quad$ S-curve path of crime growth in Mexico (data source [4]).

practice of corruption and impunity over the last decades. However, it appears that whatever the vast majority of Mexicans do in order to effect real change, powerful influences have tended to maintain the status quo ante.

\subsubsection{The judicial system}

The judicial system is intended to ensure the compliance of the Mexican Constitution over the legislations and edicts by the federal executive, including the state executives, or the legislative system. Depite of the significant efforts put over the last decade to improve the reliability of this system, it is still characterised by the endemic practice of corruption and impunity. Very often inappropriate political interferences in the legal system, deny Mexicans the right for an effective justice system.

\subsubsection{The legislative system}

This system is in charge of passing new laws and deliberating normative policies and plans with the aim of a better future for the total Mexico system. They deliberate the existing state of affairs that includes crime, with a view of creating a new vision of the future. However, they very often begin by acknowledging the accepted categories by which those affairs are discussed and analysed. They all speak of health, education, welfare, and security just as if it were not the same person, who is well or ill, educated or uneducated, nurtured or mal-nurtured, cared for or abandoned, and victim or offender. This means that the problems of the total mexico system are always multi-faceted. They are not crime problems, 
health problems, economic problems or human rught problems, as they are addressed in the legislative system. They are just problems with crine, poverty, health, etc. and they are all about people. These issues are not approached in the context of the system generating them.

\subsubsection{The executive system}

This system, at all levels of recursion, is in charged of implementing the normative plans and actions with the aim of improving the conditions of the total Mexico system. In relation to crime, the federal, states and district executives are at the top level of the law enforcement system. Their main function is inter alia to execute policies and plans in order to ensure the safety and security to the whole country. Typically, these policies and action plans are bound by the categorisation that produces crime problems to the total Mexico system. There is very little thought in deciding whether this system is fit for purpose or not. Moreover, it is not clear what that purpose is. The common practice is to approach crime in a reductionistic manner rather than seeing it as the consequence of systemic interactions between the elements of the whole system. And the essence of this preferred approach is coersive rather than effective control of crime.

\section{Concepts of a crime regulatory system}

\subsection{The control problem}

Under the influence of corruption and impunity practice, the total Mexico system changes to the current unstable system, i.e., characterised by a steadily growth of crime of all kind (Figure 2). The total Mexico system is acted by the endemic practice of corruption and impunity and is changed to unstable system, i.e., characterised by high levels of crime, poor economic growth, increasing health problems of its inhabitants, etc. (Figure 3). The dashed double arrow head line represents the ineffective interaction between the government management system, at different levels of recursion, and the total Mexico system. This is, it depicts unfit for purpose of the total management system.

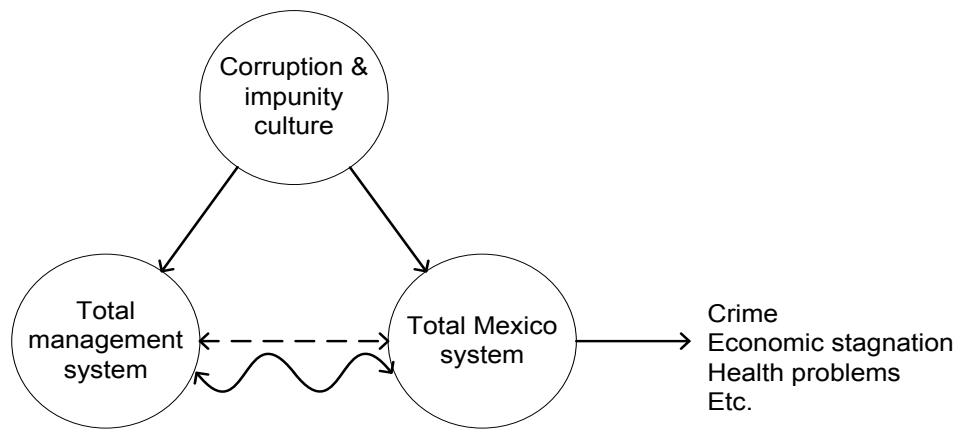

Figure 3: Current crime control system in Mexico. 
The double arrow head wavy line on the other hand indicates the existence of corruption and impunity actions in the interaction between the total country management system and the total Mexico system. The change that occurs, which is represented by the total Mexico system and the solid arrow line on the right is the transition. This transition is intended to be specified by the states and the indication of which changes to which.

\subsection{Control concept development}

From the existing crime control system, as depicted in Figure 3, one can deduce that the total management system of the total Mexico system needs to be influenced by an effective democratic management system practice in order to enable a more radical transformation of the total Mexico system. This in turn eventually will transit to a steady state of progress not only in disrupting crime growth (Figure 2), but also in other issues such as the economy, health, and education. Figure 4 depicts a conceptual model of the new control system.

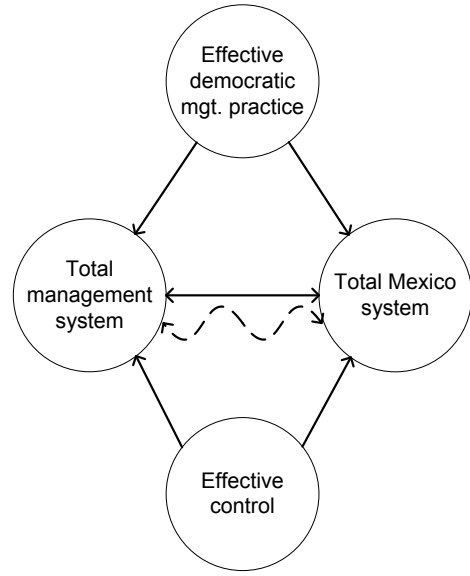

(a)

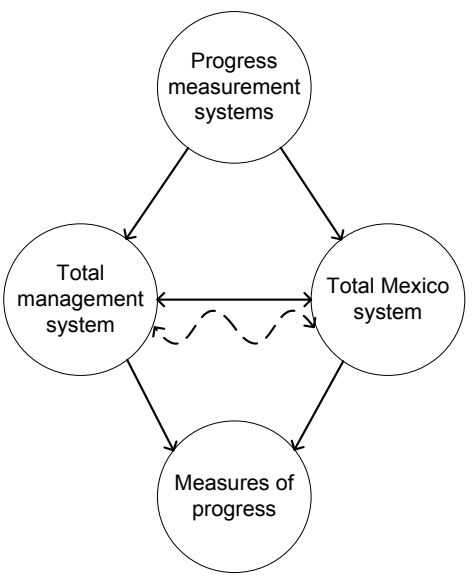

(b)

Figure 4: An effective crime control system concept.

A fundamental principle of control is that an effective regulation of any complex system is itself involving the interplay of different dimensions of control. This is the meaning of the effective control element in the conceptual model depicted in Figure 4(a). The concept implies that the total Mexico system controls itself in the same way the total management of the country should control itself. This is not about the deployment of the army or the creation of new police forces to confront crime systems. It is about ensuring the system of values that the whole system at all levels of recursion is supposed to support. In doing so, it should be able to monitor and control the interplay of different conditions of economic, health, education, political and social activities, amongst other key control dimensions. It is not a reactive approach it is proactive or preventive approach to control crime. In order to implement an effective control 
system, just in the same way they are implemented in industrial processes, the propose control model incorporates measurements systems as a vital part of the control system (Figure 4(b)). The traditional saying: 'if you cannot measure it, you cannot control it' is certainly a valid principle for both the control engineers as well as the social systems control engineer.

\section{Conclusions and further research}

This paper described on ongoing process of the design of a regulatory system to control crime in Mexico. It first recognised the endemic culture of corruption and impunity that enable crime growth in a steady S-shaped path. Crime has taken around one hundred years to reach its midpoint of growth. Once this path has been identified, the next step was to formulate a control system concept, which intends to ensure that the whole system and its recursive levels do no deviate from the intended system of values, i.e., the set point in the sense of control engineering terminology. Future work includes detail design of the developed regulatory system concept.

\section{References}

[1] Santos-Reyes, D. and Santos-Reyes, J., (2007), Patterns and rates of crime evolution in Mexico, WIT Transactions on the Built Environment, pp. 119127.

[2] Santos-Reyes, D.E., and Santos-Reyes, J.R, (2012), International Journal of Safety and Security Engineering, Volume 2, Number 1, pp. 54-68.

[3] Piccato, P., (2003), A historical perspective on crime in twentieth-century Mexico City. In: Center for U.S.-Mexican Studies. Project on Reforming the Administration of Justice in Mexico.

[4] Piccato, P., (2006), Estadísticas del crimen en México: Series históricas, 1901-2001. In: Columbia University. http://www.columbia.edu/ pp 143/ estadisticascrimen/EstadisticasSigloXX.

[5] Buffington, R, (2003), Periodisation and its discontents: the social construction of crime and criminality in modern Mexico. In: Center for U.S.-Mexican Studies. Project on Reforming the Administration of Justice on Mexico. http://repositories.cdlib.org/usmex/prajm/buffington.

[6] Arango, D., and Medina, L., (2006), Análisis y tendencia del delito en México (1997-2002). In: Seguridad Pública en México. http://www. seguridadpublicaenmexico.org.mx/estudios\%20sobre\%20mexico/menu_2.

[7] Gorsky, Y.M., Stepanov, A.M., and Teslinov, A.G., (2000), Homeostatic: science of the twenty-first century, Kybernetes, Vol. 29, No. 9/10, pp. 11501165 .

[8] Gorsky, Y.M., and Stepanov, A.M., (2003), Homeostatics as a science of controlling contraditions of various natures, Kybernetes, Vol. 32, No. 9/10, pp. $1515-1529$. 